\title{
Berwirausaha Kopi Di Masa Pandemi Corona Virus Disease 19 Di Kecamatan Medan Labuhan
}

\author{
Teuku Fahmi 1*, Fandi Alfiansyah Siregar², Muhammad Anshar ${ }^{3}$ \\ Jurusan Ilmu Administrasi Bisnis, Universitas Dharmawangsa Medan, \\ Jl. KL. Yos Sudarso No. 224-Medan 20114 \\ * Penulis Korespodensi : anshar@dharmawangsa.ac.id
}

\begin{abstract}
Abstrak : Kebijakan Walikota Medan yang mengeluarkan peraturan daerah tentang pembatasan sosial berskala besar memaksa pemilik wirausaha kedai kopi untuk menutup usahanya selama beberapa beberapa bulan. Tujuan penelitian ini untuk mengetahui strategi pemilik kedai kopi dalam berwirausaha di masa pandemi covid 19, mengetahui mekanisme komunikasi berwirausaha yang dilakukan pemilik kedai kopi dan mengetahui kendala - kendala yang dihadapi oleh pemilik kedai kopi. Penelitian ini merupakan penelitian deskriptif kualitatif dengan menggunakan metode survei dan observasi dan teknik pengambilan datanya diukur menggunakan wawancara dan dokumentasi. Pemerintah pusat maupun daerah belum memberikan bantuan kepada pemilik kedai kopi berupa suntikan dana untuk tetap bisa bertahan dan berwirausaha dimasa pandemi covid 19 ini. Pemerintah kota Medan sudah selayaknya membuat kebijakan bersama para pelaku usaha dikota Medan pada umumnya terkhususnya pemilik kedai kopi yang mempunyai modal terbatas dan Pemilik kedai kopi harus mempunyai terobosan ide-ide dan inovasi baru dalam berwirausaha untuk menghadapi masa pandemi covid 19 yang belum berakhir
\end{abstract}

Kata Kunci : Berwirausaha, Covid 19, Kopi

\begin{abstract}
The Medan Mayor's policy of issuing a regional regulation on large-scale social restrictions forced the coffee shop entrepreneur to close down his business for several months. The purpose of this study was to determine the strategy of coffee shop owners in entrepreneurship during the Covid 19 pandemic, to find out the entrepreneurial communication mechanisms carried out by coffee shop owners and to find out the obstacles faced by coffee shop owners. This research is a qualitative descriptive study using survey and observation methods and data collection techniques are measured using interviews and documentation. The central and local governments have not provided assistance to coffee shop owners in the form of injections of funds to stay afloat and be entrepreneurial during the Covid 19 pandemic. The Medan city government should make joint policies with business actors in the city of Medan in general, especially coffee shop owners who have limited capital and coffee shop owners must have breakthrough ideas and new innovations in entrepreneurship to face the Covid 19 pandemic that has not ended.
\end{abstract}

Keywords: Entrepreneurship, Covid 19, Coffee 


\section{A. Pendahuluan}

Sektor usaha di Indonesia didominasi oleh usaha mikro, kecil dan menengah (99\%) dan menjadi sumber pendapatan bagi $97 \%$ tenaga kerja di Indonesia (Kementerian Koperasi dan Usaha Kecil Menengah : 2015). Pandemi COVID-19 tidak saja berdampak pada perusahaan besar tetapi juga berdampak pada kelangsungan usaha kecil dan menengah dan pekerjanya. Penurunan dan penjualan pendapatan serta terganggunya distribusi bahan baku sebagai imbas COVID-19 menyebabkan pelaku usaha mengurangi kegiatan produksi bahkan menghentikan produksi. Kondisi ini berpengaruh pada penggunaan tenaga kerja.

Kementerian Koperasi dan UKM mencatat sebanyak 37.000 pelaku usaha kecil menengah terkena dampak COVID-19 (Rakhma dan Setiawan : 2020). Diperkirakan jumlahnya jauh lebih besar karena tidak semua pelaku usaha mikro, kecil dan menengah yang berjumlah 56 ribu lebih, melaporkan kondisi usahanya. Sementara itu, data Kemenaker per 27 Mei 2020 mencatat dampak COVID-19 menyebabkan jumlah pekerja sektor formal yang telah dirumahkan sebanyak 1.058.284 orang dan pekerja sektor formal yang di PHK sebanyak 380.221 orang. Sedangkan, sektor informal yang terdampak COVID-19 sebanyak 318.959 orang. total pekerja sektor formal dan informal yang terdampak COVID-19 sebanyak 1.757.464 orang. (Devi Asiati, Kemenaker : 2020).

Kebijakan walikota medan yang mengeluarkan peraturan daerah tentang PSBB memaksa pemilik wirausaha kedai kopi untuk menutup usahanya selama beberapa minggu sampai beberapa bulan. Hal ini dilakukan oleh pemerintahan kota medan untuk menekan angka penyebaran dan angkat kematian yang disebabkan oleh wabah pandemi Covid 19. Kelonggaran untuk wirausaha dilakukan oleh pemerintah kota medan untuk menekan angka pengangguran dan kebrangkutan tempat-tempat usaha kecil menengah salah satunya kedai kopi dengan menetapkan protokal kesehatan di dalam berwirausahanya.

Strategi merupakan salah satu bagian dari unsur-unsur dalam manajemen, setiap kegiatan harus mempunyai strategi, tanpa strategi yang baik kegiatan tidak berjalan dengan baik. Strategi dipakai segala bidang dan aspek kehidupan tanpa terkecuali baik di sektor pemerintahaan maupun sektor swasta. Pemilik (Owner) harus mempunyai strategi yang baik di dalam kebijakan bisnisnya untuk menghadapi wabah pandemi covid 19, hal ini agar kedai kopi yang dijalankan tetap bisa eksis dan bertahan. Peneliti melihat beberapa kedai kopi di daerah kelurahan Besar Martubung Kecamatan Medan Labuhan dapat bertahan di dalam perekonomian yang sulit di masa wabah pandemi saat ini.

Penelitian ini merupakan penelitian deskriptif kualitatif dengan menggunakan metode survei dan observasi dan teknik pengambilan datanya diukur menggunakan wawancara dan dokumentasi. Data sub variabel akan dijabarkan dalam faktor strategi, komunikasi dan kendala. Setiap pemilik kedai kopi (Owner) memiliki perancanaan masing-masing seperti kekuatan, kelemahaan, peluang dan ancaman. Masa Covid 19 merupakan sebuah ancaman bagi semua pemilik kedai kopi, dilihat dari profit keuntungan sebelum dan semasa adanya pandemi. Perencanaan setiap pemilik kedai kopi yang berwirausaha di daerah kecamatan medan labuhan hampir sama tidak jauh beda, yakni memaksimalkan produk kopi yang ada, menonjolkan ciri khas kedai kopinya, memanfaatkan pemasaran penjualan secara online baik promosi maupun yang lainnya dari segi kekuatan dan peluang. Faktor kelemahan dari pemilik kedai kopi dari perencanaan ini adalah, terbatasnya dana anggaran sehingga pemilik kedai kopi memberhentikan sementara waktu tempat usahanya seperti di 
anugerah kopi selama 1-2 bulan dikarenakan surat edaran dari pemerintah kota medan untuk menutup tempat usaha di masa pandemi pertama merebak di kota medan. Strategi manajemen organisasi yakni salah satunya kerja sama tim (team work), disiplin, inisiatif, stabilitas hubungan kerja dan keadialan. Pemilik kedai kopi menjaga hubungan baik dengan para pegawai walaupun adanya pengurangan sumber daya manusia (pemberhentian pegawai sementara) dengan memberikan kompensasi sesuai dengan kemampuan keuangan pemilik kedai disaat tempat usaha kopi berhenti sementara waktu, pengurangan upah gaji pegawai disaat keuntungan profit tidak sebesar sebelum pandemi. Hal ini dilakukan untuk pemilik kedai kopi bisa berwirausaha selama pandemi covid 19.

\section{B. Metode}

Penelitian ini akan diteliti di kedai kopi yang ada di Kecamatan Medan Labuhan, Waktu penelitian dilaksanakan selama 3 (tiga) bulan dari Agustus 2020 hingga Oktober 2020.Penelitian ini lebih menggunakan pendekatan deskriptif kualitatif. Pendekatan kualitatif diharapkan mampu menghasilkan uraian yang mendalam tentang ucapan, tulisan, dan atau organisasi tertentu dalam suatu setting konteks tertentu yang dikaji dari sudut pandang yang utuh, komprehensif, dan holistik. Dalam memilih sample penelitian kualitatif menggunakan teknik non probabilitis, yaitu suatu teknik pengambilan sample yang tidak didasarkan pada rumusan statistic tetapi lebih pada pertimbangan subyektif peneliti dengan didasarkan pada jangkauan dan kedalaman masalah yang diteliti dalam penelitian ini. Subjek di sini berasal dari subjek penelitian yang merupakan bagian penting dalam penelitian, karena dengan adanya subjek ini berarti peneliti dapat melakukan penelitian dengan memfokuskan pada kumpulan subjek tersebut. Subjek menjadi sebuah identitaaas tempat ataupun kelompok yang menjadi objek penelitian dan berusaha untuk menjelaskan bagian-bagian yang terkandung di dialamnya ke dalam bentuk laporan penelitian. Subjek penelitian secara keseluruhan mengenai tempat dimana penelitian dilakukan dan ditujukan kepada siapa penelitian ini dilakukan.

Objek Selanjutnya setelah penentuan subjek penelitian, peneliti kemudian dapat menentukan objek penelitian yang menjadi narasumber untuk kepentingan perolehan informasi. Konsekuensi pemilihan informan berasal dari adanya informan yag berasal dari subjek penelitian yang tidak tergantung pada jumlahnya. Saja tetapi lebih terfokus pada kualitasinforman yang akan digunakan. Informan ini kemudian dalam penelitian kualitatif disebut sebagai informan. Dengan ketersedian informasi yang ada, maka dibutuhkan suatu teknik penarikan informan menggunakan teknik penarikan informan, purposive. Teknik penarikan informan dengan menggunakan purposive dipilih karena teknik ini memilih orang (informan) dengan berbagai penilaian tertentu menurut kebutuhan peneliti sehingga dianggap layak untuk dijadikan sumber informasi atau narasumber. Sebagaimana yang dikatakan oleh Jalaluddin Rakhmat bahwa, "Purposif, yaitu memilih orang-orang tertentu karena dianggap berdasarkan penilaian tertentu"(Rakhmat,1997:81).

Fokus informan dalam penelitian ini adalah Pemilik (Owner) kedai kopi. Penarikan informan pada penelitian ini menggunakan random atau penarikan informan secara purposive. Teknik wawancara dengan menggunakan kejenuhan data, dimana jika ada jawaban yang sama antara responden satu dengan lainnya maka peneliti tidak akan bertanya lagi dan membatasinya.

Teknik pengumpulan data yang digunakan dalam penelitian ini, diantaranya dengan Penelitian Lapangan (Field Research), 
teknik yang dapat digunakan diantaranya, adalah :

Wawancara (Interview), yaitu merupakan salah satu metode pengumpulan berita, data dan fakta. Wawancara bertujuan menggali informasi, komentar, opini, fakta, atau data tentang suatu masalah atau peristiwa dengan mengajukan pertanyaan kepada narasumber atau orang yang diwawancarai (interview). Field Research dengan wawancara langsung ke sumber infroman yaitu pemilik warung kopi/kafe (owner) serta peracik minuman (Barrista Kopi). Wawancara dilakukan selama 15-30 menit per owner atau barrista kopinya yang berkaitan langsung dengan permasalahan yang dihadapi. Pemilik kedai kopi maupun barrista merespon pertanyaan dan wawancara dengan peneliti dengan sangat baik dalam hal menjawab pertanyaan peneliti.

Observasi, yaitu mengadakan pengamatan terhadap objek penelitian dengan melakukan pencatatan terhadap fenomena yang ada di lapangan. Dalam hal ini peneliti mengamati secara langsung di kedai kopi selama 60 menit per kedai kopi setiap minggunya.

Analisis data adalah proses penyederhanaan data ke dalam bentuk yang lebih mudah dibaca dan dipersentasikan (Singarimbun,1995:263). Penelitian ini bersifat deskriptif, yaitu penelitian yang memberikan gambaran mengenai situasisituasi atau kejadian-kejadian. Analisis data dalam penelitian ini berlangsung bersamaan dengan proses pengumpulan data. Diantaranya meliputi tiga jalur, yaitu : reduksi data, penyajian data dan penarikan kesimpulan.

Penyajian data merupakan sekumpulan informasi tersusun yang memberi kemungkinan adanya penarikan kesimpulan dan pengambilan tindakan. Penarikan kesimpulan juga mencakup verifikasi atas kesimpulan.

Kesimpulan-kesimpulan diverifikasi selama penelitian berlangsung dengan cara memikirkan ulang selama penulisan., tinjauan ulang pada catatancatatan lapangan, Penunjauan kembali dan tukar pikiran antar teman sejawat untuk mengembangkan "kesepakatan intersubjektif", upaya-upaya yang luas untuk menempatkan salinan suatu temuan dalam seperangkat data yang lain. Teknik analisis data juga dijelaskan oleh Kriyanto (2006:194), "data kualitatif dapat berupa kata-kata, kalimat-kalimat atau narasi-narasi, baik yang diperoleh dari wawancara mendalam maupun observasi".

Proses Analisis Data Penelitian

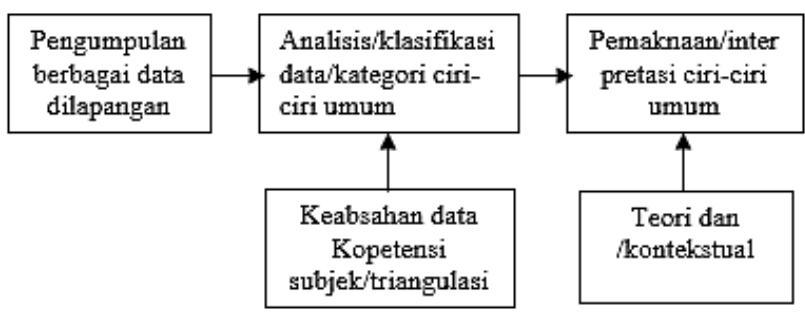

Hasil dan Pembahasan

Kecamatan Medan labuhan adalah salah satu dari 21 kecamatan di kota Medan, Sumatra Utara, Indonesia. Kecamatan Medan Labuhan berbatasan dengan Medan Marelan di sebelah barat, Kabupaten Deli Serdang di timur, Medan Deli dan Kabupaten Deli Serdang di selatan, dan Medan Belawan di utara. Pada tahun 2001, kecamatan ini mempunyai penduduk sebesar 89.245 jiwa. Luasnya adalah 40,68 $\mathrm{km}^{2}$ dan kepadatan penduduknya adalah $2.433,72 \mathrm{jiwa} / \mathrm{km}^{2}$. 


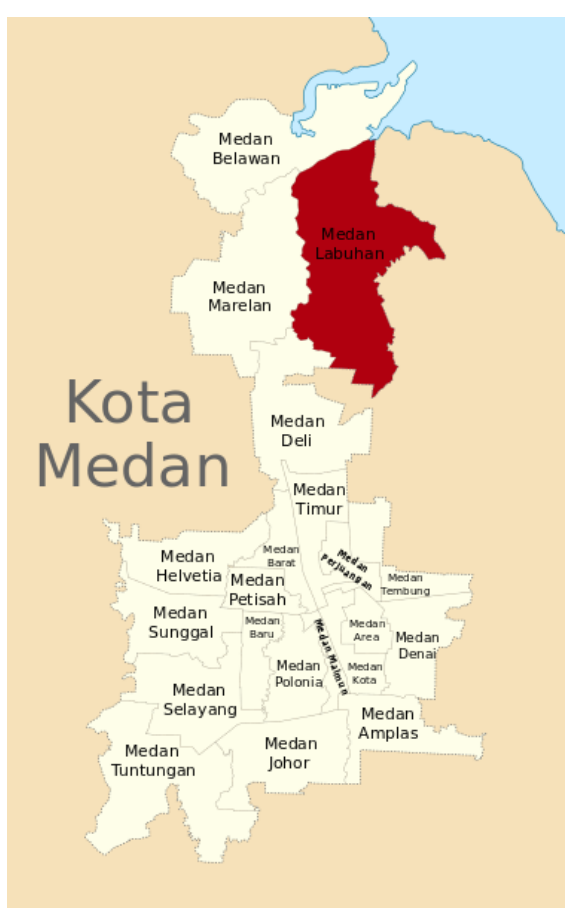

Sumber

https://id.wikipedia.org/wiki/Medan Labuha $\underline{\text { n, Medan }}$

Keadaan Geografis kecamatan Medan Labuhan Kecamatan Medan Labuhan berbatasan langsung dengan kecamatan Medan Deli di sebelah selatan, kecamatan Medan Belawan di sebelah utara, kecamatan Medan Marelan di sebelah barat, dan kabupaten Deli Serdang di sebelah timur. Kecamatan Medan Labuhan merupakan salah satu kecamatan di Kota Medan yang mempunyai luas sekitar 41,275 km2. Jarak kantor kecamatan ke kantor wali kota Medan yaitu sekitar $18 \mathrm{~km}$.

Dari enam kelurahan di kecamatan Medan Labuhan, kelurahan Sei Mati memiliki luas wilayah yang terluas yaitu sebesar 12,870 km2 sedangkan kelurahan Pekan Labuhan mempunyai luas terkecil yakni 3,600 km2. Ditinjau dari jarak antara kantor kelurahan dan kantor kecamatan, kantor kelurahan Tangkahan dan Nelayan Indah memiliki jarak terjauh dari kantor kecamatan Medan Labuhan yaitu sekitar $4 \mathrm{~km}$ sedangkan kantor kelurahan yang terdekat yaitu kelurahan Martubung sekitar 0,6 km dari kantor kecamatan Medan Labuhan.

\begin{tabular}{|c|c|c|}
\hline Kelurahan & $\begin{array}{c}\text { Luas } \\
\left(\mathrm{Km}^{2}\right)\end{array}$ & $\begin{array}{c}\text { Persentase } \\
\text { Terhadap LUas } \\
\text { Kecamatan (\%) }\end{array}$ \\
\hline (1) & (2) & (3) \\
\hline Besar & 6,000 & 14,57 \\
\hline Tangkahan & 6,005 & 14,55 \\
\hline Martubung & 8,000 & 19,38 \\
\hline Sei Mati & 12,870 & 31,18 \\
\hline $\begin{array}{l}\text { Pekan } \\
\text { Labuhan }\end{array}$ & 3,600 & 8,72 \\
\hline $\begin{array}{l}\text { Nelayan } \\
\text { Indah }\end{array}$ & 4,800 & 11,63 \\
\hline TOTAL & 41,275 & 100 \\
\hline
\end{tabular}

Sumber : Kantor Camat Medan Labuhan

Dilihat dari besarnya luas dari kecamatan, pastilah jumlah kedai kopi sangat banyak, sehingga peneliti hanya mengambil sample dari banyaknya sebaran kedai kopi di kecamatan medan labuhan. Sample ini mewakili sebaran kedai kopi yang diteliti oleh peneliti.

Berdasarkan data dari Badan Pusat Statistik tahun 2017, jumlah Penduduk kecamatan Medan Labuhan sebanyak 139.480 penduduk terdiri dari 64.744 orang laki-laki 
serta 74.736 perempuan. Berdasarkan kelompok umur, distribusi penduduk kecamatan Medan Labuhan relatif lebih banyak di kelompok umur 15-44 tahun. Dilihat dari segi kewarganegaraannya, ternyata tidak terdapat warga negara asing yang berdomisili di kecamatan Medan Labuhan.

Penduduk tercatat sebanyak 352 penduduk yang lahir sepanjang tahun $2016 \mathrm{di}$ kecamatan Medan Labuhan, sedangkan 147 orang yang meninggal. Mobiltas penduduk di kecamatan inipun juga cukup ramai yakni selama tahun 2016 tercatat 309 orang datang dan 219 orang pindah dari kecamatan ini, Sebagaian besar penduduk di kecamatan ini adalah suku-suku pendatang sedangkan suku asli Suku Melayu Deli 40\% saja.

\subsubsection{Data Penelitian}

Ada Banyak kedai kopi di kecamatan medan labuhan, tim peneliti hanya mengambil sampel yang berjumlah 6 kedai kopi dari jumlah kedai kopi yang tersebar di kecamatan medan labuhan. Hal ini dikarenakan lagi masa pandemi covid 19, adanya pembatasan sosial berskala besar (PSSB) yang dilakukan oleh pemerintah kota medan serta adanya larangan untuk berkerumun di tempat umum dan pemerintah kota medan selalu mengadakan razia dimasa $\mathrm{PSBB}$ ini.

Terdapat lima (6) kedai kopi yang diteliti oleh tim peneliti diantaranya :

\begin{tabular}{|c|c|c|}
\hline No & $\begin{array}{c}\text { Nama Kedai } \\
\text { Kopi }\end{array}$ & Alamat Kedai Kopi \\
\hline 1 & $\begin{array}{l}\text { Anugerah } \\
\text { Coffee }\end{array}$ & $\begin{array}{lll}\text { Komplek } & \text { MU } & \text { City } \\
\text { Martubung } & & \\
\end{array}$ \\
\hline 2 & Otw Coffee & $\begin{array}{lll}\text { Komplek } & \text { MU } & \text { City } \\
\text { Martubung } & & \end{array}$ \\
\hline 3 & $\begin{array}{l}\text { Sudut } \\
\text { Nostalgia }\end{array}$ & $\begin{array}{llll}\text { Jl. Pancing } & \mathrm{V} & \mathrm{gg} & \mathrm{Al} \\
\text { Hidayah } & & & \end{array}$ \\
\hline
\end{tabular}

\begin{tabular}{|l|l|lll|}
\hline 4 & Kala Sore & $\begin{array}{l}\text { Jl. Pancing } \\
\text { Labuhan }\end{array}$ & Medan \\
\hline 5 & AR Coffee Lab & $\begin{array}{l}\text { Jl. Rawe } \\
\text { Labuhan }\end{array}$ & Medan \\
\hline 6 & $\begin{array}{l}\text { Opa Coffee } \\
\text { and More }\end{array}$ & $\begin{array}{l}\text { Jl. KL Yos Sudarso no. 9 } \\
\text { RW Medan Labuhan }\end{array}$ \\
\hline
\end{tabular}

Sumber Data : Tim Peneliti, 2020

Profit Laba Keuntungan bruto dan Netto perbulan sebelum dan semasa pandemi covid 19:

\begin{tabular}{|c|c|c|c|c|}
\hline $\begin{array}{l}\text { Nama } \\
\text { Kedai } \\
\text { Kopi }\end{array}$ & $\begin{array}{l}\text { Profit } \\
\text { Bruto } \\
\text { Sebelu } \\
\mathrm{m} \\
\text { Covid } \\
\text { (Bulan) }\end{array}$ & $\begin{array}{l}\text { Profit } \\
\text { Netto } \\
\text { Sebelu } \\
\text { m } \\
\text { Covid } \\
\text { (Bulan) }\end{array}$ & $\begin{array}{l}\text { Profit } \\
\text { Bruto } \\
\text { Semas } \\
\text { a } \\
\text { Covid } \\
\text { (Bulan } \\
\text { ) }\end{array}$ & $\begin{array}{l}\text { Profit } \\
\text { Netto } \\
\text { Semas } \\
\text { a } \\
\text { Covid } \\
\text { (Bulan } \\
\text { ) }\end{array}$ \\
\hline $\begin{array}{l}\text { Anugera } \\
\text { h Coffee }\end{array}$ & $\begin{array}{l}10-15 \\
\text { Juta }\end{array}$ & $\begin{array}{l}8-12 \\
\text { Juta }\end{array}$ & $\begin{array}{l}5-10 \\
\text { Juta }\end{array}$ & $\begin{array}{l}5-7 \\
\text { Juta }\end{array}$ \\
\hline $\begin{array}{l}\text { Otw } \\
\text { Coffee }\end{array}$ & $\begin{array}{l}10-15 \\
\text { Juta }\end{array}$ & $\begin{array}{l}8-12 \\
\text { Juta }\end{array}$ & $\begin{array}{l}\text { 5-10 } \\
\text { Juta }\end{array}$ & $\begin{array}{l}5-7 \\
\text { Juta }\end{array}$ \\
\hline $\begin{array}{l}\text { Sudut } \\
\text { Nostalgi } \\
\text { a }\end{array}$ & $\begin{array}{l}\text { 10-15 } \\
\text { Juta }\end{array}$ & $\begin{array}{l}8-12 \\
\text { juta }\end{array}$ & $\begin{array}{l}5-10 \\
\text { Juta }\end{array}$ & $\begin{array}{l}5-7 \\
\text { Juta }\end{array}$ \\
\hline $\begin{array}{l}\text { Kala } \\
\text { Sore }\end{array}$ & $\begin{array}{l}10-15 \\
\text { Juta }\end{array}$ & $\begin{array}{l}8-12 \\
\text { juta }\end{array}$ & $\begin{array}{l}5-10 \\
\text { Juta }\end{array}$ & $\begin{array}{l}5-7 \\
\text { Juta }\end{array}$ \\
\hline $\begin{array}{l}\text { AR } \\
\text { Coffee } \\
\text { Lab }\end{array}$ & $\begin{array}{l}\text { 10-15 } \\
\text { Juta }\end{array}$ & $\begin{array}{l}8-12 \\
\text { juta }\end{array}$ & $\begin{array}{l}5-10 \\
\text { Juta }\end{array}$ & $\begin{array}{l}5-7 \\
\text { Juta }\end{array}$ \\
\hline $\begin{array}{l}\text { Opa } \\
\text { Coffee } \\
\text { and } \\
\text { more }\end{array}$ & $\begin{array}{l}10-20 \\
\text { Juta }\end{array}$ & $\begin{array}{l}8-15 \\
\text { juta }\end{array}$ & $\begin{array}{l}\text { 5-15 } \\
\text { Juta }\end{array}$ & $\begin{array}{l}5-10 \\
\text { Juta }\end{array}$ \\
\hline
\end{tabular}

Sumber Data : Tim Peneliti, 2020 


\section{Hasil dan Pembahasan}

Setiap pemilik kedai kopi (Owner) memiliki perancanaan masing-masing seperti kekuatan, kelemahaan, peluang dan ancaman. Masa Covid 19 merupakan sebuah ancaman bagi semua pemilik kedai kopi, dilihat dari profit keuntungan sebelum dan semasa adanya pandemi. Perencanaan setiap pemilik kedai kopi yang berwirausaha di daerah kecamatan medan labuhan hampir sama tidak jauh beda, yakni memaksimalkan produk kopi yang ada, menonjolkan ciri khas kedai kopinya, memanfaatkan pemasaran penjualan secara online baik promosi maupun yang lainnya dari segi kekuatan dan peluang. Faktor kelemahan dari pemilik kedai kopi dari perencanaan ini adalah, terbatasnya dana anggaran sehingga pemilik kedai kopi memberhentikan sementara waktu tempat usahanya seperti di anugerah kopi selama 1-2 bulan dikarenakan surat edaran dari pemerintah kota medan untuk menutup tempat usaha di masa pandemi pertama merebak di kota medan. Salah satu strategi manajemen organisasi yakni salah satunya kerja sama tim (team work), disiplin, inisiatif, stabilitas hubungan kerja dan keadilan. Pemilik kedai kopi menjaga hubungan baik dengan para pegawai walaupun adanya pengurangan sumber daya manusia (pemberhentian pegawai sementara) dengan memberikan kompensasi sesuai dengan kemampuan keuangan pemilik kedai disaat tempat usaha kopi berhenti sementara waktu, pengurangan upah gaji pegawai disaat keuntungan profit tidak sebesar sebelum pandemi. Hal ini dilakukan untuk pemilik kedai kopi bisa berwirausaha selama pandemi covid 19.

\section{Kesimpulan dan Saran}

Urgensi penelitian ini yaitu Covid 19 melumpuhkan sendi perekonomian Indonesia baik dipemerintahan maupun disektor swasta, baik yang berskala besar maupun kecil. Hal ini disebabkan banyak pembatasan yang dilakukan oleh pemerintah untuk mencegah meningkatnya penularan covid 19. Pembatasan-pembatasn inilah yang mengakibatkan perekoniman menurun drastis, banyaknya pemutusan kontrak kerja (PHK) yang dilakukan perusahaan besar/kecil, pembatasan ruang gerak sosial dan ekonomi, dan lainya. Pemilik kedai kopi yang berwirausaha di kawasan kecamatan medan labuhan rata-rata merupakan usaha kecil menengah (UKM) pastilah sangat berdampak hal ini disebabkan hanya mempunyai modal terbatas / kecil. Panjangnya masa pandemi covid 19 sampai saat ini 2021 membuat pemilik usaha kedai kopi tidak mempunyai harapan yang banyak yang penting bisa bertahan berwirausahanya atau bahkan menutup sementara waktu tempat usaha kedai kopinya. Pemerintah kota medan mengeluarkan instruksi PSBB di masa covid 19 dan melakukan razia kerumunan khalayak ramai seperti tempat usaha kopi sehingga mengurangi pendapatan pemilik kedai kopi dan tidak adanya bantuan dari pemerintah pusat maupun daerah kepada pemilik kedai kopi berupa suntikan dana untuk tetap bisa bertahan dan berwirausaha dimasa pandemi covid 19 ini. Seharusnya Pemerintah kota Medan memberikan bantuan berupa suntikan dana tambahan kepada pemilik usaha dikota pada umumnya dan khususnya kepada pemilik kedai kopi di kecamatan medan labuhan, Pemerintah kota Medan membuat kebijakan bersama para pelaku usaha dikota Medan pada umumnya terkhususnya pemilik kedai kopi yang mempunyai modal terbatas dan Pemilik kedai kopi harus mempunyai terobosan ide-ide dan inovasi baru dalam berwirausaha untuk menghadapi masa pandemi covid 19 yang belum berakhir. 


\section{Daftar Pustaka}

Budiman Dicky, Naibaho Hastuti, dan Amelia. (2013).Pengaruh Kualitas Layanan, Kualitas Produk, Kepuasan Pelanggan Terhadap Kesetiaan Merek Starbuck Di Surabaya. Jurnal. Universitas Pelita Harapan Surabaya. Surabaya.

Kasali, Renald. (2010). Change. Gramedia Pustaka. Jakarta.

Kluytmans, Fritz. (2006). Perilaku Manusia. PT Refika Aditama. Bandung

Kotler, Philip. (2003). Marketing Management 11th Edition. Prentice Hall. New Jersey.

Kotler, Philip dan Kevin L. keller. (2009). Manajemen pemasaran. Erlangga. Jakarta.

Marastika, Vivin. (2015). Gaya Hidup Minum Kopi Pemuda di Kota Palembang (Studi Kasus pada Pemuda Penikmat Kopi di Starbucks Coffee Palembang Icon Mall). Jurnal. Universitas Sriwijaya. Inderalaya.

Moleong, L.J. (2007). Metodologi Penelitian Kualitatif. Remaja Rosadakarya. Bandung.

Nurazizi, Reza Dwiyan. (2013). Kedai Kopi Dan Gaya Hidup Konsumen (Analisis Simulacrum Jean P Baudrillard Tentang Gaya Hidup Ngopi di Excelso). Jurnal. Universitas Brawijaya. Malang.

Perwita, Kiki Diah. (2012). Analisis Customer Relations Kedai Kopi Espresso Bardi Yogyakarta Dalam Meningkatkan dan Mempertahankan Konsumen.

Skripsi. Universitas Pembangunan Nasional "VETERAN". Yogyakarta.

Schiffman, Leon G dan Leslie, Lazar Kanuk. (2010). Principles of Marketing 12th Edition Prentice Hall International Inc. New Jersey.

Sudaryana, Arif. (2014). Memahami Motivasi Dalam Proses Keputusan Pembelian
Konsumen. Jurnal. Universitas PGRI Yogyakarta. Yogyakarta.

Sugiyono. (2009). Metode Penelitian Bisnis. Penerbit Alfabeta. Bandung.

Saefulla. Manajemen Pendidikan Islam. Bandung: Pustaka Setia, 2012.

Sarbini. Perencanaan Pendidikan. Bandung: Pustaka Setia, 2001.

Siagian, Sondang. Fungsi-Fungsi Manajerial. Jakarta: PT Bumi Aksara, 2002.

Sugiyono.Metode Penelitian Manajemen. Bandung: Alfabeta, 2014.

Sugiyono. Metode Penelitian Kombinasi. Bandung: Alfabeta CV, 2015.

Sugiyono.Metode Penelitian Kuantitatif Kualitatif dan R\&D. Bandung: Alfabeta, 2013.

Sugiyono. Statistik Untuk Penelitian. Bandung: Alfabeta, 2010.

Sutrisno,Edy. Manajemen Sumber Daya Manusia. Jakarta: Kencana, 2009.

Syaroh,Muya. Peran komunikasi antar pribadi. Medan, 2016.

Terry.Dasar-dasar Manajemen. Jakarta: PT Bumi Aksara,2000.

Terry. Prinsip-Prinsip

Manajemen.Jakarta: Bumi Aksara, 2003.

Tirtarahardjo, Sulola. Pengantar Pendidikan. Jakarta: PT. Rineka Cipta, 2013.

Usman, Husaini. Manajemen Teori, Praktek \& Riset Pendidikan. Jakarta: Bumi Aksara, 2008.

https://kependudukan.lipi.go.id/id/berita/53 -mencatatcovid19/975-strategi-bertahahidup-bagi-pelaku-usaha-dan-pekerja-ditengah-pandemi-covid-19 